\title{
The potential benefits of low-molecular-weight heparins in cancer patients
}

\author{
Francisco Robert ${ }^{*}$
}

\begin{abstract}
Cancer patients are at increased risk of venous thromboembolism due to a range of factors directly related to their disease and its treatment. Given the high incidence of post-surgical venous thromboembolism in cancer patients and the poor outcomes associated with its development, thromboprophylaxis is warranted. A number of evidencebased guidelines delineate anticoagulation regimens for venous thromboembolism treatment, primary and secondary prophylaxis, and long-term anticoagulation in cancer patients. However, many give equal weight to several different drugs and do not make specific recommendations regarding duration of therapy. In terms of their efficacy and safety profiles, practicality of use, and cost-effectiveness the low-molecular-weight heparins are at least comparable to, and offer several advantages over, other available antithrombotics in cancer patients. In addition, data are emerging that the antithrombotics, and particularly low-molecular-weight heparins, may exert an antitumor effect which could contribute to improved survival in cancer patients when given for long-term prophylaxis. Such findings reinforce the importance of thromboprophylaxis with low-molecular-weight heparin in cancer patients.
\end{abstract}

\section{Introduction}

Venous thromboembolism (VTE), comprising deep vein thrombosis (DVT) and pulmonary embolism (PE), is one of the principal causes of morbidity and mortality in surgical patients [1]. The development of post-surgical VTE is associated with significantly higher rates of hospital readmission, VTE recurrence, and a greater than 3-fold increase in mortality [2]. Cancer patients are at additional risk of VTE [3], and following cancer surgery VTE is the most common cause of death at 30 days [4].

The probability of diagnosing concomitant cancer is up to 10-times greater for cases of idiopathic VTE compared with those where the pre-disposing risk factor is known $[5,6]$. In a recent systematic review, the reported 12-month prevalence for cancer following VTE was $10.0 \%$ (95\% confidence interval [CI]: 8.6-11.3) in patients with idiopathic VTE compared with $2.6 \%$ (95\% CI: 1.63.6) in those with a provoked VTE [7]. Overall, around $10-20 \%$ of all non-cancer patients who present with idiopathic VTE develop cancer over the following 3 years [8]. The association between VTE and cancer is so

\footnotetext{
*Correspondence: pacorobertuab@cs.com Department of Medicine, Division of Hematology/Oncology, Comprehensive Cancer Center, University of Alabama at Birmingham, 1802 6th Avenue South, NP CC-2555, Birmingham, AL 352943300, USA
}

pronounced that some researchers have argued that patients with idiopathic VTE be screened for occult cancer [7].

The risk of VTE in cancer patients varies according to disease-specific factors such as the location, stage, and type of the malignancy $[3,9]$. In addition, cancer patients typically present with a number of co-morbid conditions that predispose individuals to thrombosis, such as older age and frequent hospitalization [10,11]. Cancer patients undergoing surgery have up to twice the risk of DVT and three-times the risk of $\mathrm{PE}$ as non-cancer patients undergoing similar operations $[12,13]$. VTE risk is further increased by cancer therapies, with significant increases in VTE in cancer patients treated with chemoand hormonal-therapy $[11,14,15]$. There is, therefore, a clear need for thromboprophylaxis in surgical cancer patients which is supported by current guidelines [1,16-19]. This review summarizes the relative merits of the low-molecular-weight heparins (LMWHs) and the other principal anticoagulants used for thromboprophylaxis in this high-risk population.

\section{Pathophysiology of VTE and cancer}

Although the relationship between cancer and VTE was first recognized almost 150 years ago [20], the molecular basis of this association has only recently been 
investigated. Studies have shown a complex pathophysiology involving perturbation of multiple components within the coagulation and fibrinolytic pathways. The association between cancer and VTE works both ways, with cancer inducing a hypercoagulable state and the pro-thrombotic changes in turn facilitating cancer growth and metastasis [21]. Cancer cells have been shown to aberrantly express several components involved in coagulation. For example, tissue factor, a key activator of the coagulation cascade, is expressed on endothelial cells, monocytes and, most importantly, on tumor cells themselves and is thought to play a pivotal role in cancer-induced hypercoagulability [21]. In addition, cancerous cells can produce a cysteine proteinase, termed cancer procoagulant, which directly cleaves factor $\mathrm{X}$ to $\mathrm{Xa}$ leading to the generation of thrombin and thrombus formation [22]. von Willebrand factor (vWF) promotes platelet adhesion during thrombus formation and elevated vWF levels have been detected in various cancers [23]. Aberrant expression of glycoprotein IIb/ IIIa receptors, which are involved in platelet activation and adhesion, and serve to promote and stabilize thrombi, is also observed on tumor cells [24].

Cancer is also associated with disturbances of the fibrinolytic system. Plasmin, which breaks down fibrin clots, is produced from its precursor molecule plasminogen in response to plasminogen activator or urokinasetype plasminogen activator, and is inhibited by plasminogen activator inhibitor [25]. However, deregulation of these factors is observed in cancer patients, resulting in disruptions to the normal process of clot lysis [25]. Cancer patients may, therefore, possess abnormal expression of a number of factors which are crucial for normal hemostasis, resulting in a general state of hypercoagulability. In addition to their hemostatic effects, many of these molecules are also involved in other physiological systems, most notably angiogenesis. Many components of the coagulation cascade are also involved in tumor neovascularization, tumor cell growth, and metastasis [21]. This has particular relevance for the anti-neoplastic effects of the various antithrombotics as discussed later.

\section{Thromboprophylaxis in cancer patients}

Several evidence-based guidelines are available that delineate appropriate anticoagulation regimens for VTE treatment, primary and secondary prophylaxis, and long-term anticoagulation in cancer patients [1,16-19]. However, despite the existence of these guidelines and the high-risk of VTE in cancer patients, up to $75 \%$ of cancer patients do not receive appropriate prophylaxis [26]. Cancer patients are significantly less likely than non-cancer patients to have received thromboprophylaxis prior to DVT occurrence [27]. In a sub-group analysis of the Epidemiologic International Day for the
Evaluation of Patients at Risk for Venous Thromboembolism in the Acute Hospital Care Setting (ENDORSE) [28] worldwide study comprising 1,767 cancer patients undergoing abdominal, gynecological or urological surgery, $27.7 \%$ of patients did not receive appropriate thromboprophylaxis [29].

The use of thromboprophylaxis in cancer patients is complicated by the fact that although they are at an increased risk of VTE, they are also at an increased risk of bleeding [30,31]. Given that the risk of VTE outweighs the risk of bleeding in most cancer patients [30,31], the use of antithrombotic agents which provide stable anticoagulation while minimizing bleeding complications is especially important in this high-risk population. In addition, the available guidelines are not always consistent in their recommendations, often give several drugs equally weighted recommendation, and do not always specify the appropriate treatment duration [1,16-19]. Given these ambiguities, it can be difficult for oncologists to make informed decisions about which anticoagulant and treatment regimen would be of most benefit to their patients.

\section{Choosing the appropriate thromboprophylactic agent}

The principal role of the antithrombotics in surgical patients is to provide effective anticoagulation over the course of the increased risk of VTE (during and postsurgery) with the minimum of adverse events such as post-operative bleeding. For cancer patients, there is also increasing evidence that antithrombotics may possess anti-neoplastic effects and are potentially associated with a reduced incidence of cancer and increased survival times when given for long-term prophylaxis [32]. Such findings reinforce the importance of thromboprophylaxis in oncology patients.

When deciding which drug to prescribe, each thromboprophylactic agent can be assessed in terms of three main properties; their efficacy and safety profiles, practicality of use, and cost-effectiveness. The relative merits of the major anticoagulants according to these criteria, as well as any possible anti-neoplastic effects are discussed below.

\section{Efficacy and safety profiles Primary prophylaxis}

A meta-analysis of historical studies performed before thromboprophylaxis was routinely prescribed, demonstrated that low-dose unfractionated heparin (UFH) significantly reduced the risk of combined symptomatic and asymptomatic DVT compared with no prophylaxis $(8.7 \%$ vs. $25.2 \% ; \mathrm{p}<0.001)$ in patients undergoing moderate- and high-risk general surgery, without increasing major bleeding $(0.33 \%$ vs. $0.33 \%$; $p=0.99)$. In a sub-analysis limited to cancer patients, UFH reduced the 
incidence of DVT from $30.6 \%$ to $13.3 \%$ ( $<$ 0.001) [33]. Later meta-analyses comparing UFH and LMWHs have shown that the LMWHs are at least as effective in the primary prophylaxis of VTE after general surgery [34-36] and more effective following major orthopedic surgery [35,37], with comparable or reduced risk of bleeding.

A systematic review of 26 randomized controlled trials comprising 7,639 cancer surgery patients highlighted the importance of post-operative thromboprophylaxis with either UFH or LMWH in these high-risk patients. The overall incidence of combined symptomatic and asymptomatic DVT was reduced from $35.2 \%$ in controls to $12.7 \%$ in those who received pharmacological prophylaxis [38]. However, few studies have directly compared UFH and LMWH in cancer patients (Table 1) [39-45].

The Enoxaparin and Cancer (ENOXACAN) study compared the LMWH enoxaparin and UFH in 1,115 patients undergoing abdominal or pelvic cancer surgery. Enoxaparin (40 mg once daily [OD]) was associated with a significantly lower rate of combined symptomatic and asymptomatic VTE than UFH 5,000 IU three-times daily ( $14.7 \%$ vs. $18.2 \%$, respectively; $95 \%$ CI of the difference: -9.2 to -2.3$)$ without increasing the risk of major bleeding $(4.1 \%$ vs. $2.9 \% ; p=$ not significant) [40]. A recent systematic review compared the outcomes in cancer patients who received peri-operative thromboprophylaxis with LMWH or UFH, and also found them to be comparable in terms of efficacy (combined symptomatic and asymptomatic DVT: relative risk [RR] 0.73; 95\% CI: 0.23-2.28) and safety (major bleeding: RR 0.95; 95\% CI: 0.51-1.77). However, in a post-hoc analysis of DVT incidence irrespective of diagnostic modality, LMWH was found to be superior to UFH (DVT: RR 0.72; 95\% CI: 0.55-0.94) [46].

The Pentasaccharide General Surgery Study (PEGASUS) trial compared VTE prophylaxis following major abdominal surgery (including cancer surgery) between the synthetic pentasaccharide fondaparinux $(2.5 \mathrm{mg}$ started 6 hours after surgery) and the LMWH dalteparin started 2 hours before the operation (first two doses at 2,500 IU, and thereafter 5,000 IU daily). In a sub-group analysis of cancer patients $(n=1,408)$ the combined symptomatic and asymptomatic VTE rate was $4.7 \%$ with fondaparinux compared with $7.7 \%$ in the dalteparin group (RR reduction [RRR] 38.6\%; 95\% CI: 6.7-59.6). The rate of major bleeding was not significantly different $(3.4 \%$ vs. $2.5 \%$, respectively; $\mathrm{p}=0.355)$ [44].

Overall, the available evidence indicates that thromboprophylaxis significantly reduces the risk of VTE in cancer patients undergoing surgery, and that for primary prophylaxis the LMWHs are at least comparable to UFH in terms of efficacy and safety. There are currently limited data directly comparing LMWH with fondaparinux in cancer patients.

\section{Extended-duration primary thromboprophylaxis}

Increased risk of VTE following major surgery has been shown to extend for several weeks post-operatively $[4,47,48]$. The prospective, observational @RISTOS project evaluated the incidence and timings of clinically overt VTE across a wide spectrum of patients undergoing cancer surgery. The study reported that the mean time to VTE following cancer surgery was 17.2 days (range, 2-58), with $40 \%$ of cases occurring more than 21 days post-operatively. However, these timings exceed the standard duration of prophylaxis which has historically been limited to inpatient therapy. Accordingly, cancer surgery patients receiving only inpatient thromboprophylaxis may be at risk of late VTE events. In the @RISTOS project, $81.7 \%$ of cancer surgery patients received in-hospital thromboprophylaxis, whereas only $30.7 \%$ continued to receive prophylaxis following discharge [4].

There is considerable evidence to suggest that extended-duration thromboprophylaxis may benefit cancer patients (Table 2) [48-50]. The ENOXACAN II study demonstrated that extended-duration prophylaxis with the LMWH enoxaparin (40 mg OD for 27-31 days) significantly reduced the combined incidence of symptomatic and asymptomatic VTE in cancer patients undergoing abdominal surgery compared with those receiving enoxaparin $40 \mathrm{mg}$ OD for a standard duration of 6-10 days $(4.8 \%$ vs. $12.0 \%$, respectively; $\mathrm{p}=0.02)$ without increasing bleeding complications $(6.1 \%$ vs. $4.8 \%$; $\mathrm{p}=$ not significant) [48]. The Fragmin After Major Abdominal Surgery (FAME) study of the LMWH dalteparin, which comprised 400 surgical patients of whom approximately half underwent surgery for malignancy, demonstrated that extending the duration of prophylaxis from 1-4 weeks significantly reduced the incidence of VTE without increasing bleeding [49]. In a sub-analysis of cancer patients from this study, extended-duration dalteparin significantly reduced the rate of combined symptomatic and asymptomatic VTE at 4 weeks compared with placebo $(8.8 \%$ vs. $19.6 \%$, respectively; RRR $55 \% ; \mathrm{p}=0.03$ ) [50]. Taken together, these data confirm that extended-duration prophylaxis reduces VTE in this high-risk population.

\section{Prophylaxis in medical cancer inpatients}

There is a growing awareness of the risks of VTE in hospitalized medical patients. Medical patients account for approximately $60 \%$ of all hospital admissions and an estimated $50-70 \%$ of all symptomatic inpatient VTE events and $70 \%$ of all fatal PE events occur in medical, rather than surgical patients [51]. Hospitalization for non-surgical reasons is in itself a risk factor for VTE and the presence of cancer, and its corollary risk factors, further compounds the risk of developing a VTE event [11]. Accordingly, guidelines include recommendations 
Table 1 Summary of VTE and Major Bleeding Rates in Trials Comparing Primary Thromboprophylaxis Strategies in Cancer Patients

\begin{tabular}{|c|c|c|c|c|c|c|}
\hline Ref. & Cancer & $\begin{array}{l}\text { Patients, } \\
\text { N }\end{array}$ & Drug & VTE Detection & $\begin{array}{l}\text { VTE, } \\
\%\end{array}$ & Bleeding*, \% \\
\hline \multirow{2}{*}{\multicolumn{2}{|c|}{$\begin{array}{l}\text { Abdominal, } \\
\text { thoracic }\end{array}$}} & 241 & $\begin{array}{l}\text { Orgaran } 750 \\
\text { IU BID }\end{array}$ & $\begin{array}{l}\text { Asymptomatic VTE: }{ }^{125} \text { |-fibrinogen and venography. } \\
\text { Symptomatic VTE: DVT - venography; PE - chest X-ray, VPS }\end{array}$ & 10.4 & 9.0 (overall) \\
\hline & & 249 & $\begin{array}{l}\text { UFH } 5,000 \cup \\
\text { BID }\end{array}$ & & 14.9 & 10.6 (overall) \\
\hline \multirow{2}{*}{\multicolumn{2}{|c|}{$\begin{array}{l}\text { Abdominal, } \\
\text { pelvic }\end{array}$}} & 312 & $\begin{array}{l}\text { Enoxaparin } 40 \\
\text { mg SC }\end{array}$ & $\begin{array}{l}\text { Symptomatic and asymptomatic VTE: DVT - venography; PE - VPS, } \\
\text { pulmonary angiography }\end{array}$ & 14.7 & $\begin{array}{l}14.6 \text { (minor) } \\
4.1 \text { (major) }\end{array}$ \\
\hline & & 319 & $\begin{array}{l}\text { UFH 5,000 IU } \\
\text { SC TID }\end{array}$ & & 18.2 & $\begin{array}{l}14.3 \text { (minor) } \\
2.9 \text { (major) }\end{array}$ \\
\hline \multirow{2}{*}{\multicolumn{2}{|c|}{ Gynecological }} & 160 & $\begin{array}{l}\text { Embolex } \\
3,000 \text { IU OD }\end{array}$ & Asymptomatic VTE: impedance plethysmography, phlebography & 6.3 & $\begin{array}{l}16.9 \text { (wound } \\
\text { hematoma) }\end{array}$ \\
\hline & & 164 & $\begin{array}{l}\text { UFH 5,000 IU } \\
\text { TID }\end{array}$ & & $\overline{6.1}$ & $\begin{array}{l}28.7 \text { (wound } \\
\text { hematoma) }\end{array}$ \\
\hline \multirow{2}{*}{\multicolumn{2}{|c|}{ Gynecological }} & 47 & $\begin{array}{l}\text { Enoxaparin } \\
2,500 \mathrm{IU} \text { OD }\end{array}$ & $\begin{array}{l}\text { Symptomatic VTE: DVT - ultrasonography, venography; PE - VPS, } \\
\text { pulmonary anteriography }\end{array}$ & None & $\begin{array}{l}\text { No significant } \\
\text { difference (rates not } \\
\text { given) }\end{array}$ \\
\hline & & 55 & $\begin{array}{l}\text { UFH 5,000 IU } \\
\text { TID }\end{array}$ & & None & \\
\hline \multirow{2}{*}{\multicolumn{2}{|c|}{$\begin{array}{l}\text { Colorectal (all } \\
\text { patients) }^{\dagger}\end{array}$}} & 674 & $\begin{array}{l}\text { Enoxaparin } 40 \\
\text { mg SC OD }\end{array}$ & $\begin{array}{l}\text { Symptomatic and asymptomatic VTE: DVT - ultrasonography, } \\
\text { venography; PE - VPS, ultrasonography, venography, pulmonary } \\
\text { angiography }\end{array}$ & 9.4 & $\begin{array}{l}10.1 \text { (total) } 2.7 \\
\text { (major) }\end{array}$ \\
\hline & & 675 & $\begin{array}{l}\text { UFH 5,000 IU } \\
\text { SC TID }\end{array}$ & & 9.4 & $\begin{array}{l}6.2 \text { (total) } 1.5 \\
\text { (major) }\end{array}$ \\
\hline \multirow{2}{*}{\multicolumn{2}{|c|}{$\begin{array}{l}\text { Cancer sub- } \\
\text { group }\end{array}$}} & 241 & $\begin{array}{l}\text { Enoxaparin } 40 \\
\text { mg SC OD }\end{array}$ & & 13.9 & Not reported \\
\hline & & 234 & $\begin{array}{l}\text { UFH } 5,000 \mathrm{IU} \\
\text { SC TID }\end{array}$ & & 16.9 & \\
\hline \multirow{2}{*}{\multicolumn{2}{|c|}{$\begin{array}{l}\text { Abdominal } \\
\text { (all patients) }^{\dagger}\end{array}$}} & 1,425 & $\begin{array}{l}\text { Dalteparin } \\
5,000 \text { IU OD }\end{array}$ & $\begin{array}{l}\text { Symptomatic and asymptomatic VTE: DVT - ultrasonography, } \\
\text { venography; PE - lung scan, pulmonary angiography, helical } \\
\text { computed tomography, autopsy }\end{array}$ & 6.1 & 2.5 (major) \\
\hline & & 1,433 & $\begin{array}{l}\text { Fondaparinux } \\
2.5 \mathrm{mg} \text { SC OD }\end{array}$ & & 4.6 & 3.4 (major) \\
\hline \multirow{2}{*}{\multicolumn{2}{|c|}{$\begin{array}{l}\text { Cancer sub- } \\
\text { group }\end{array}$}} & 712 & $\begin{array}{l}\text { Dalteparin } \\
5,000 \text { IU OD }\end{array}$ & & 7.7 & Not reported \\
\hline & & 696 & $\begin{array}{l}\text { Fondaparinux } \\
2.5 \mathrm{mg} \mathrm{SC} \mathrm{OD}\end{array}$ & & $\overline{4.7}$ & \\
\hline \multirow{2}{*}{\multicolumn{2}{|c|}{ Colorectal }} & 486 & $\begin{array}{l}\text { Enoxaparin } 40 \\
\text { mg SC OD }\end{array}$ & $\begin{array}{l}\text { Symptomatic and asymptomatic VTE: DVT - ultrasonography, } \\
\text { venography; PE pulmonary angiography, autopsy }\end{array}$ & 12.6 & 11.5 (major) \\
\hline & & 464 & $\begin{array}{l}\text { Nadroparin } \\
2,850 \text { IU OD }\end{array}$ & & 15.9 & 7.3 (major) \\
\hline
\end{tabular}

BID, twice daily; DVT, deep vein thrombosis; OD, once daily; PE, pulmonary embolism; SC, subcutaneous; TID, three times daily; VPS; ventilation perfusion scan; VTE, venous thromboembolism; UFH, unfractionated heparin.

*For definitions of major bleeding see original studies.

${ }^{\dagger}$ Included non-cancer patients.

for routine thromboprophylaxis in medical cancer patients [1,16-19]. However, in the Fundamental Research in Oncology and Thrombosis (FRONTLINE) survey only $5 \%$ of medical oncologists reported that they routinely used VTE prophylaxis in their cancer patients [52].

Trials investigating thromboprophylaxis in medical patients hospitalized for acute medical illnesses have reported clinical benefits in terms of a significant reduction in VTE without increasing the rates of major bleeding [53-55]. In the Prophylaxis in Medical Patients with Enoxaparin (MEDENOX) study, the use of the LMWH enoxaparin (40 mg subcutaneous [SC] OD) for 6-14 days significantly reduced the incidence of combined symptomatic and asymptomatic VTE compared with placebo $(5.5 \%$ vs. $14.9 \%$, respectively; RR 0.37 ; 97.6\% CI: 0.22-0.63; $\mathrm{p}<0.001)$. Major bleeding occurred in $1.7 \%$ of patients treated with enoxaparin compared with $1.1 \%$ in the placebo group [53]. In a sub-group analysis of patients that had active or previously 
Table 2 Summary of VTE and Major Bleeding Rates in Trials Comparing Extended-Duration Thromboprophylaxis Strategies in Cancer Patients

\begin{tabular}{|c|c|c|c|c|c|c|}
\hline Ref. & Cancer & $\begin{array}{l}\text { Patients, } \\
\mathrm{N}\end{array}$ & Drug & VTE Detection & VTE, \% & $\begin{array}{l}\text { Bleeding*, } \\
\%\end{array}$ \\
\hline & \multirow{2}{*}{$\begin{array}{l}\text { Gastrointestinal, } \\
\text { genitourinary, } \\
\text { gynecological }\end{array}$} & 167 & $\begin{array}{l}\text { Enoxaparin } 40 \text { mg SC 6-10 } \\
\text { days plus placebo 19-21 days }\end{array}$ & $\begin{array}{l}\text { Symptomatic and asymptomatic VTE: DVT - } \\
\text { venography; PE - VPS, pulmonary angiography }\end{array}$ & 12 & $\begin{array}{l}3.6 \text { (minor) } \\
3.6 \text { (major) }\end{array}$ \\
\hline & & 165 & $\begin{array}{l}\text { Enoxaparin } 40 \text { mg SC } 25-31 \\
\text { days }\end{array}$ & & 4.8 & $\begin{array}{l}4.7 \text { (minor) } \\
5.1 \text { (major) }\end{array}$ \\
\hline & \multirow[t]{2}{*}{$\begin{array}{l}\text { Abdominal (all } \\
\text { patients) }\end{array}$} & 178 & $\begin{array}{l}\text { Dalteparin } 5,000 \text { IU OD plus } \\
\text { GCS for } 7 \text { days }\end{array}$ & $\begin{array}{l}\text { Symptomatic and asymptomatic VTE: DVT - } \\
\text { venography; PE - VPS, spiral computerized }\end{array}$ & 16.3 & $\begin{array}{l}0.9 \text { (minor) } \\
1.8 \text { (major) }\end{array}$ \\
\hline & & 165 & $\begin{array}{l}\text { Dalteparin 5,000 IU SC OD plus } \\
\text { GCS for } 7 \text { days, plus further } 21 \\
\text { days }\end{array}$ & & 7.3 & $\begin{array}{l}1.5 \text { (minor) } \\
0.5 \text { (major) }\end{array}$ \\
\hline & \multirow[t]{2}{*}{$\begin{array}{l}\text { Abdominal cancer } \\
\text { sub-group }\end{array}$} & 198 total & $\begin{array}{l}\text { Dalteparin } 5,000 \text { IU OD plus } \\
\text { GCS for } 7 \text { days }\end{array}$ & & $\begin{array}{l}19.6 \\
\text { proximal } \\
\text { DVT: } 10.4\end{array}$ & $\begin{array}{l}\text { Not } \\
\text { reported }\end{array}$ \\
\hline & & & $\begin{array}{l}\text { Dalteparin 5,000 IU SC OD plus } \\
\text { GCS for } 7 \text { days, plus further } 21 \\
\text { days }\end{array}$ & & $\begin{array}{l}8.8 \\
\text { proximal } \\
\text { DVT: } 2.2\end{array}$ & \\
\hline
\end{tabular}

DVT, deep vein thrombosis; GCS, graduated compression stockings; OD, once daily; PE, pulmonary embolism; SC, subcutaneous; VPS; ventilation perfusion scan; VTE, venous thromboembolism.

* For definitions of major bleeding see original studies.

${ }^{\dagger}$ Included non-cancer patients

diagnosed cancer, VTE rates were $19.5 \%(8 / 41)$ in the placebo group compared with $9.7 \%(3 / 31)$ in those treated with enoxaparin (RR 0.50;95\% CI: 0.14-1.72; p = 0.4) [56].

Likewise in the Prospective Evaluation of Dalteparin Efficacy for Prevention of VTE in Immobilized Patients Trial (PREVENT), which included 3,706 medical inpatients, of which 190 had cancer, the use of dalteparin (5,000 IU SC OD) for 14 days reduced the combined incidence of symptomatic and asymptomatic VTE from $4.96 \%$ in the placebo group to $2.77 \%$ (RR 0.55 ; $95 \% \mathrm{CI}$ : $0.38-0.80 ; \mathrm{p}=0.0015)$. Major bleeding was not significantly increased in the dalteparin group compared with placebo (0.49\% vs. $0.16 \%$, respectively; $\mathrm{p}=0.15$ ) [54].

In the Arixtra for Thromboembolism Prevention in a Medical Indications Study (ARTEMIS), 849 medical inpatients were randomized to receive fondaparinux $(2.5$ mg SC OD) or placebo for 6-14 days [55]. In patients with previous or current cancer VTE occurred in $17 \%$ (95\% CI: 7.6-30.8) of the fondaparinux group compared to $3.9 \%$ (95\% CI: $0.5-13.5)$ of the placebo group [57]. However, it should be noted that in all these trials cancer patients represented a sub-group of the total medical patients enrolled and accordingly any conclusions based on these data should reflect the relatively small sample sizes.

Whilst guidelines delineate the appropriate clinical responses for medical inpatients bedridden with cancer or cancer patients hospitalized for a medical illness, they are less clear regarding ambulatory outpatients, and patients receiving highly thrombogenic chemotherapy. For instance, the American College of Chest Physicians (ACCP) guidelines recommend that all cancer patients bedridden with an acute medical illness receive thromboprophylaxis (Grade 1A), but caution against routine thromboprophylaxis in medical patients receiving chemotherapy (Grade 1 C) [1]. Similarly, the American Society of Clinical Oncology (ASCO) guidelines advocate that all hospitalized cancer patients receive thromboprophylaxis, but recommend against routine thromboprophylaxis in ambulant cancer patients receiving chemotherapy [17]. The ASCO guidelines also recommend that ambulant patients receiving thalidomide or lenalidomide with chemotherapy or dexamethasone receive thromboprophylaxis with a VKA targeted to an INR of 1.5 [17]. The Italian Association of Medical Oncology (AIOM) recommend that hospitalized cancer patients confined to bed receive thromboprophylaxis with a LMWH (Level of evidence (LOE) I, Grade A), but do not recommend routine prophylaxis in advanced cancer patients receiving chemotherapy (LOE II, Grade B) or in ambulatory cancer patients receiving adjuvant chemotherapy or hormone therapy (LOE I, Grade A) [16]. In contrast, the National Comprehensive Cancer Network (NCCN) guidelines recommend that patients on highly thrombogenic chemotherapy be considered for thromboprophylaxis, but do not specify the preferred pharmacotherapeutic strategy [19].

Recently, risk assessment models (RAMs) have been developed specifically for VTE risk in cancer patients 
[58-60]. These models assign cancer patients with a overall VTE risk score by 'adding' thrombogenic risk factors from a variety of patient-, cancer- and treatment-related factors including age, race and immobility status, together with site or stage of the cancer, whether or not the patient is receiving chemotherapy, presence of biomarkers such as platelet count, tissue factor or Ddimer levels [58-60]. These risk scores can aid in determining who is at risk of VTE and warrant thromboprophylaxis.

\section{Secondary/long-term prophylaxis}

Guidelines recommend that the use of the oral anticoagulant warfarin in cancer patients is limited to longterm secondary prophylaxis following a VTE event or for long-term anticoagulation $[18,19]$. The guidelines note that cases of VTE should be initially treated with either UFH or a LMWH $[18,19]$, or LMWH $[16,17]$. In a recent systematic review of the literature, the use of LMWH over UFH for the initial treatment of VTE was associated with significantly reduced mortality rates in cancer patients (RR 0.71; 95\% CI: 0.52-0.98) [61]. Data on bleeding were unavailable for this analysis.

As a result of their suitability for outpatient use, the LMWHs can also be considered for use in secondary/ long-term prophylaxis, a role traditionally performed by warfarin. In a meta-analysis of studies investigating the efficacy and safety of long-term treatment of VTE, the LMWHs were associated with non-significant reductions in the rates of recurrent symptomatic and asymptomatic VTE (odds ratio [OR] 0.66; 95\% CI: 0.41-1.07) and major bleeding (OR 0.45; 95\% CI: 0.18-1.11) compared with oral anticoagulants [62]. In cancer patients, treatment of VTE with the LMWH dalteparin was associated with a lower rate of symptomatic, objectively confirmed recurrent thromboembolism compared with warfarin $(8.0 \%$ vs. $15.8 \%$, respectively; hazard ratio [HR] $0.48 ; \mathrm{p}=$ $0.002)$, without increasing the rate of major bleeding (6\% vs. $4 \%)$ or any bleeding (14\% vs. $19 \%$ ) [63]. Similar findings were reported in a study comparing long-term treatment with the LMWH tinzaparin with warfarin; 7\% of patients treated with tinzaparin and $16 \%$ of those treated with warfarin experienced symptomatic, objectively confirmed recurrent VTE (RR 0.44; 95\% CI: -21.7 to $-0.7 ; p=0.044$ ) [64]. Bleeding, which was largely minor, occurred in $27 \%$ of patients receiving tinzaparin and $24 \%$ receiving warfarin (absolute difference -3.0 ; 95\% CI: -9.1 to 15.1 ).

A recent systemic review concluded that LMWHs for long-term treatment of VTE in patients with cancer reduce VTE compared with warfarin (HR 0.47; 95\% CI: $0.32-0.71$ ) [65]. There was no statistically significant difference between the LMWHs and warfarin in bleeding outcomes in this study (RR 0.91; 95\% CI: 0.64-1.31). On the strength of these findings the available guidelines increasingly recommend the LMWHs over warfarin for VTE treatment [16-19].

\section{Practicality of use}

The use of UFH is complicated by its narrow therapeutic range, resulting in frequent monitoring of activated partial thromboplastin time or anti-Xa levels, and dose adjustments may be required during treatment [66]. UFH has sub-optimal bioavailability and accordingly when it is given subcutaneously it requires much larger doses than when given intravenously to achieve equivalent anticoagulation levels [67]. The heterogonous assortment of molecules that make up UFH result in a highly polygamous mixture capable of binding multiple plasma proteins, macrophages, and endothelial cells [68]. Accordingly, resulting anticoagulation responses to UFH can vary widely. In contrast, the LMWHs have higher bioavailability [69] and, because of their reduced plasma protein binding, have a more predictable pharmacokinetic profile [70] and a longer half-life [68]. Unlike UFH which is hepatically cleared, the LMWHs are renally excreted. As such, monitoring may be required in certain patient populations, including the morbidly obese, those with severe renal impairment, and pregnant women [68]. However, in the majority of patients, the pharmacokinetic advantages of the LMWHs mean they can be effectively administered without the need to monitor the anticoagulant effect, both in inpatient and outpatient settings.

\section{Outpatient use}

Although warfarin has historically been the mainstay of long-term thromboprophylaxis, its use is complicated by its narrow therapeutic window and the difficulty in maintaining appropriate levels of anticoagulation [71]. Warfarin is affected by numerous interactions with a wide-range of drugs, nutritional supplements and herbal remedies, and its efficacy can be affected by vomiting and diarrhea, all of which are common in cancer patients. Intolerance, hypersensitivity, and resistance to warfarin leading to treatment failure have all been reported [71]. The effectiveness of warfarin is especially compromised in cancer patients [72]. Compared with matched controls, cancer patients on warfarin spent significantly less time inside the target international normalized ratio (INR) range (both supra- and subtherapeutic, $54 \%$ vs. $64 \%$, respectively; $\mathrm{p}<0.001)$, had more variable INR values $(\mathrm{p}<0.001)$, and had more thrombotic events compared with matched non-cancer patients $(\mathrm{p}<0.001)$ [72]. Warfarin use in cancer patients undergoing chemotherapy results in extra utilization of hospital resources, especially through increased day visits associated with warfarin monitoring and resulting laboratory costs [73]. A further potential limitation of warfarin therapy is that it has a slow onset and long 
duration of action (half-life 36-42 hours) [74], which can represent a problem if anticoagulation needs to be interrupted quickly for invasive procedures, as is frequently the case in cancer patients.

The principal practical advantage of the LMWHs in the outpatient setting, both for extended-duration primary prophylaxis and long-term secondary prophylaxis, is the lack of a need to monitor anticoagulation in the majority of patients. Patient compliance with LMWHs is high in both non-cancer [75] and cancer populations $[76,77]$, with the majority of patients being comfortable with self-administration. Outpatient thromboprophylaxis in cancer patients with SC LMWH is associated with a good safety profile and a high level of compliance [77]. In a study of VTE treatment in cancer patients, LMWH was associated with improved quality-of-life over warfarin, primarily on the basis of reduced blood tests and increased optimism regarding therapy [78]. Similarly in a pharmacoeconomic analysis using data from the Comparison of Low Molecular Weight Heparin Versus Oral Anticoagulant Therapy for Long Term Anticoagulation in Cancer Patients With Venous Thromboembolism (CLOT) trial which compared the LMWH dalteparin and warfarin for the long-term anticoagulation of cancer patients with DVT, dalteparin was the preferred treatment in $96 \%(23 / 24)$ of respondents and was associated with a gain of 0.157 quality-adjusted life years (QALY) [79].

Overall, therefore, LMWHs offer considerable advantages over warfarin in cancer patients in terms of practicality of use as well as in efficacy.

\section{Cost comparisons}

The costs involved in managing VTE in general are considerable. In the US managing DVT alone is estimated to cost around $\$ 1.5$ billion annually [80]. The yearly direct costs for treating an individual VTE episode are high; $\$ 10,804$ for a DVT event and $\$ 16,644$ for a PE event [81]. Furthermore, the long-term sequelae of VTE such as post-thrombotic syndrome can further increase costs [82]. Accordingly, the expenditure associated with the provision of appropriate anticoagulation following surgery can be offset by the savings achieved by averting the costs of VTE management.

A number of studies have indicated that the LMWHs are economically superior to UFH both for DVT treatment $[80,83,84]$, and for bridging to long-term anticoagulation [85-87], and they are at least non-inferior or superior to warfarin in preventing VTE following orthopedic surgery $[88,89]$. However, there are limited data regarding the economics associated with thromboprophylaxis following cancer surgery. Data from the CLOT trial on long-term prophylaxis in cancer patients with DVT showed that overall costs were lower with warfarin than dalteparin (CA $\$ 2,003$ vs. $\$ 4,262$, respectively; $\mathrm{p}<$ 0.001 ), primarily due to reduced drug-acquisition costs [79]. However, when patient quality of life was also included in the analysis dalteparin therapy was associated with a cost of around CA $\$ 13,800$ per QALY gained [79], far below the $\$ 50,000$ cost per QALY considered to be economically acceptable [90].

\section{Anticoagulants may be associated with increased survival in cancer patients}

Three major studies have indicated that the LMWHs may be associated with a survival benefit in cancer patients that could not be directly linked to a reduction in VTE incidence [91-93]. In the Malignancy and Low Molecular Weight-Heparin Therapy (MALT) trial, cancer patients were randomly assigned to 6-weeks of either the LMWH nadroparin $(n=148)$ or placebo $(n=154)$. At 12 months the overall HR for death was 0.75 (95\% CI: 0.59-0.96) with a median survival of 8.0 months in the nadroparin group compared with 6.6 months in the placebo group [91]. Similarly, The Fragmin Advanced Malignancy Outcome Study (FAMOUS) compared the LMWH dalteparin given for 1-year with placebo in cancer patients. The Kaplan-Meier survival estimates for 1, 2 , and 3 years after randomization were not different between the dalteparin and placebo groups $(\mathrm{p}=0.19)$. However, in an analysis not planned a priori, a subgroup of patients who were alive at 17 months, experienced significantly improved survival estimates at 2- and 3 -years following randomization with dalteparin versus placebo ( $78 \%$ vs. $55 \%$ and $60 \%$ vs. $36 \%$, respectively; $\mathrm{p}=$ $0.03)$ with no increase in major bleeding rates [92]. Notably, these effects were observed long after dalteparin was discontinued, suggesting the survival benefit is not dependent on VTE prophylaxis.

In the CLOT trial, over 600 patients with cancer and VTE were randomized to receive 6-months of warfarin or dalteparin therapy. A survival benefit for LMWH over warfarin was observed in patients with non-metastatic cancer, with a $20 \%$ mortality rate in the dalteparin group compared with $36 \%$ with warfarin (HR 0.50; $95 \%$ CI: $0.27-0.95 ; \mathrm{p}=0.03)$. However this benefit was not maintained in patients with metastatic cancer (72\% vs. $69 \%$, respectively; HR 1.1; 95\% CI: $0.87-1.4 ; \mathrm{p}=0.46$ ) [93].

Although some studies have suggested that warfarin may also improve survival in cancer patients [94,95] and reduce the incidence of cancer [96], a meta-analysis of 11 studies comparing mortality with the LMWHs versus warfarin demonstrated that although the LMWHs increased survival (RR 0.877; 95\% CI: 0.789-0.975; p = 0.015) warfarin did not (RR 0.942; 95\% CI: 0.854-1.040; $\mathrm{p}=0.239$ ) [32]. Furthermore, patients receiving warfarin therapy also had a significant increase in the risk of 
major bleeding (RR 2.979; 95\% CI: 2.134-4.157; p < 0.0001 ) whereas those receiving LMWH did not (RR 1.678; 95\% CI: $0.861-2.269, \mathrm{p}=0.128$ ). In a systematic review of the literature, heparin (UFH or LMWH) was associated with a survival benefit in cancer patients (HR $0.77,95 \%$ CI $0.65-0.91$ ) without significantly increasing the risk of bleeding (RR 1.78, 95\% CI 0.73-4.38) [97]. When analyzed by subgroups however, a statistically significant survival benefit was observed in patients with limited small-cell lung cancer (SCLC) (HR 0.56, 95\% CI 0.38-0.83), but was not seen in patients with more extensive SCLC (HR 0.80, 95\% CI 0.60-1.06) or patients with advanced disease (HR 0.84, 95\% CI 0.68-1.03) [97].

Thus it appears that the LMWHs may be associated with improved survival in certain cancer populations. However, more studies are needed to fully characterize this effect and how it is affected by different cancer locations, types, and disease stage. Accordingly, current evidence-based guidelines delineating appropriate thromboprophylaxis and VTE-treatment in cancer patients do not recommend the use of primary thromboprophylaxis to try to improve survival in cancer patients, and use of a LMWH for this indication would be off-label $[1,17,19]$.

Findings suggest that the improvements in survival seen with the LMWHs in cancer patients do not simply result from a decrease in the incidence of VTE, but also from potential anti-neoplastic properties of heparins. Heparin and its derivatives possess mucopolysaccharide chains similar to cell-surface and extra-cellular matrix molecules, raising the possibility that UFH and LMWHs can modulate how cells interact with their environment, enzymes, and cell-signaling molecules, and so affect malignant cell growth [98]. In vivo evidence suggests that the anti-metastatic effects of heparins depend upon P-selectin-mediated binding via their polysaccharide chains rather than their antithrombotic activity [99]. Accordingly fondaparinux, which lacks a polysaccharide chain, did not inhibit metastasis at clinically relevant anticoagulation levels in this model [99]. Similarly, UFH, LMWHs and oligosaccharide truncates of heparin have been shown to inhibit tumor growth and metastasis in vivo [100].

Heparin and oligosaccharide truncates of heparin have also been shown to inhibit angiogenesis [101]. Studies have demonstrated UFH and LMWH have dose-dependent antiangiogenic effects that are mediated via release of endothelial tissue factor pathway inhibitor, which are independent of their antithrombotic activity [102]. Furthermore, heparins can directly affect the immune system by their inhibitory effects on extravasation of leukocytes and the complement system, or by enhancing the susceptibility of cancer cells to immunologic attacks [103]. Consequently, it is likely the proposed anti- neoplastic effects of heparin and the LMWHs are a combination of direct anti-neoplastic, antiangiogenetic, and immunomodulatory effects, as well as indirect effects resulting from their pleiotropic action on the coagulation system.

Each LMWH has a particular structural profile which in turns gives it specific pharmacokinetic and pharmacodynamic properties [104,105]. Structural differences between the LMWHs such as in the molecular weight, molecule length, end-group composition, carboxyl-tosulfate group ratio and the proportion of anti-Xa binding domains have been shown to affect the biological activity of the resulting molecule [104,105]. It is possible therefore that the LMWHs possess different anti-metastatic properties to one another. However, it is unclear at present to what extent the structural heterogeneity between the LMWHs translates into clinical differences in the drug's anti-metastatic effect. Current research is investigating separating the anticoagulant and anti-metastatic properties of heparin molecules for use in cancer patients [106].

The complex mechanisms associated with improvements in survival of cancer patients treated with heparins are of relevance to the new generation of oral anticoagulants which are under development [107]. In an attempt to separate antithrombotic and bleeding effects, agents have been designed to inhibit specific proteins within the coagulation cascade. However, these new drugs lack the polypharmacological actions of the UFH and LMWHs which are thought to be involved in anti-neoplastic effects, and accordingly it is likely that they will also have concurrent reductions in their antineoplastic activity.

\section{Discussion}

Whilst heparin and vitamin $\mathrm{K}$ antagonists have been the mainstay of anticoagulant therapy for over fifty years, a new generation of anticoagulants are either recently available or are currently under development, which offer potential benefits over existing therapies in cancer patients $[108,109]$. For instance, as cancer patients are at an increased risk both of VTE and bleeding [30,31], cancer patients would benefit from anticoagulants that have a favorable balance of anticoagulation to hemorrhagic effects. AVE5026 is a new ultra low-weight LMWH in development whose favorable safety-to-efficacy ratio may make it particularly suitable for a cancer setting [110]. Some of the new anticoagulants, such as dabigatran [111] and rivaroxaban [112,113], are orally administered drugs that have proven effective in reducing the incidence of VTE following major orthopedic surgery. Whilst these new drugs are of potential interest in cancer because they don't require laboratory monitoring 
and are orally administered, they have yet to be fully tested in an oncology setting.

It is important to remember that the cancer populations discussed in the manuscript frequently comprise heterogeneous patient groups. The mortality rate and risk of VTE in one cancer population may not be equivalent to another population, and likewise the risks and benefits of particular anticoagulation therapies may not necessarily the same either. Furthermore, as patients with advanced cancer, renal or hepatic impairment, or with a short-term prognosis are frequently excluded from clinical trials, the patients included in clinical trials are typically in better health than cancer patients seen in clinical practice.

\section{Conclusion}

Cancer patients are at increased risk of VTE due to a range of disease-, treatment- and patient-related factors. Current evidence-based guidelines support the use of anticoagulation in at-risk surgical cancer patients, although generally there is limited specific guidance as to which anticoagulant is most appropriate, or for how long treatment should be given. Both UFH and the LMWHs are recommended for primary prophylaxis following cancer surgery. Studies show that the LMWHs are at least as effective as UFH in this setting, but are associated with a tendency towards lower bleeding. Given the period of post-operative VTE risk, data increasingly support extended-duration prophylaxis beyond the period of hospitalization. The practical and pharmacokinetic advantages of the LMWHs facilitate such treatment, and the use of LMWHs in this setting is associated with reduced hospital visits and a reduced need for blood tests/monitoring. In other patient populations these advantages mean that the LMWHs are a more cost-effective drug class than UFH, but more specific oncology-based studies are needed before this finding can be applied to cancer patients.

The LMWHs are also recommended for use in secondary/long-term prophylaxis where, compared with warfarin, they display increased efficacy with a good safety profile and reliability, and are associated with increased quality of life. In addition, the LMWHs have been associated with a potential anti-neoplastic effects which may contribute to improved survival times in cancer patients. However, more studies are needed to understand this effect, and the potential role of the LMWHs as antineoplastic therapy.

\section{Acknowledgements}

The author received editorial support in the preparation of this manuscript, funded by sanofi-aventis, NJ, USA. The author is fully responsible for content and editorial decisions for this manuscript.

\section{Competing interests}

The author declares that they have no competing interests.

Received: 9 September 2009

Accepted: 14 January 2010 Published: 14 January 2010

\section{References}

1. Geerts WH, Bergqvist D, Pineo GF, Heit JA, Samama CM, Lassen MR, Colwell CW, American College of Chest Physicians: Prevention of venous thromboembolism: American College of Chest Physicians EvidenceBased Clinical Practice Guidelines. Chest , 8 2008, 133(6 Suppl):381S-453S.

2. Mukherjee D, Lidor AO, Chu KM, Gearhart SL, Haut ER, Chang DC: Postoperative venous thromboembolism rates vary significantly after different types of major abdominal operations. J Gastrointest Surg 2008, 12:2015-2022.

3. Levitan N, Dowlati A, Remick SC, Tahsildar HI, Sivinski LD, Beyth R, Rimm AA: Rates of initial and recurrent thromboembolic disease among patients with malignancy versus those without malignancy. Risk analysis using Medicare claims data. Medicine (Baltimore) 1999, 78:285-291.

4. Agnelli G, Bolis G, Capussotti L, Scarpa RM, Tonelli F, Bonizzoni E, Moia M, Parazzini F, Rossi R, Sonaglia F, Valarani B, Bianchini C, Gussoni G: A clinical outcome-based prospective study on venous thromboembolism after cancer surgery: the @RISTOS project. Ann Surg 2006, 243:89-95.

5. Prandoni P, Lensing AW, Büller HR, Cogo A, Prins MH, Cattelan AM, Cuppini S, Noventa F, ten Cate JW: Deep-vein thrombosis and the incidence of subsequent symptomatic cancer. N Engl J Med 1992, 327:1128-1133.

6. Prandoni P, Piccioli A: Thrombosis as a harbinger of cancer. Curr Opin Hematol 2006, 13:362-365.

7. Carrier M, Le Gal G, Wells PS, Fergusson D, Ramsay T, Rodger MA: Systematic review: the Trousseau syndrome revisited: should we screen extensively for cancer in patients with venous thromboembolism?. Ann Intern Med 2008, 149:323-333.

8. Prins MH, Otten HM: Thrombosis and cancer: a short history of Trousseau's syndrome. Thrombosis and Cancer London, New York: Informa HealthcareLugassy G, Falanga A, Kakkar AK, Rickles FR 2004, 1-10.

9. Chew HK, Wun T, Harvey D, Zhou H, White RH: Incidence of venous thromboembolism and its effect on survival among patients with common cancers. Arch Intern Med 2006, 166:458-464.

10. Edwards BK, Howe HL, Ries LA, Thun MJ, Rosenberg HM, Yancik R, Wingo PA, Jemal A, Feigal EG: Annual report to the nation on the status of cancer, 1973-1999, featuring implications of age and aging on U.S. cancer burden. Cancer 2002, 94:2766-2792.

11. Heit JA, Silverstein MD, Mohr DN, Petterson TM, O'Fallon WM, Melton LJ: Risk factors for deep vein thrombosis and pulmonary embolism: a population-based case-control study. Arch Intern Med 2000, 160:809-815.

12. Gallus AS: Prevention of post-operative deep leg vein thrombosis in patients with cancer. Thromb Haemost 1997, 78:126-132.

13. Kakkar AK, Williamson RC: Antithrombotic therapy in cancer. BMJ 1999 , 318:1571-1572.

14. Haddad TC, Greeno EW: Chemotherapy-induced thrombosis. Thromb Res 2006, 118:555-568.

15. Nalluri SR, Chu D, Keresztes R, Zhu X, Wu S: Risk of venous thromboembolism with the angiogenesis inhibitor bevacizumab in cancer patients: a meta-analysis. JAMA 2008, 300:2277-2285.

16. Mandalà $M$, Falanga A, Piccioli A, Prandoni P, Pogliani EM, Labianca R, Barni S, working group AIOM: Venous thromboembolism and cancer: guidelines of the Italian Association of Medical Oncology (AIOM). Crit Rev Oncol Hematol 2006, 59:194-204.

17. Lyman GH, Khorana AA, Falanga A, Clarke-Pearson D, Flowers C, Jahanzeb M, Kakkar A, Kuderer NM, Levine MN, Liebman H, Mendelson D, Raskob G, Somerfield MR, Thodiyil P, Trent D, Francis CW, American Society of Clinical Oncology: American Society of Clinical Oncology guideline: recommendations for venous thromboembolism prophylaxis and treatment in patients with cancer. J Clin Oncol 2007, 25:5490-5505.

18. Kearon C, Kahn SR, Agnelli G, Goldhaber S, Raskob GE, Comerota AJ, American College of Chest Physicians: Antithrombotic therapy for venous thromboembolic disease: American College of Chest Physicians Evidence-Based Clinical Practice Guidelines. Chest , 8 2008, 133(6 Suppl):454S-545S. 
19. National Comprehensive Cancer Network. NCCN Clinical Practice Guidelines in Oncology. Venous Thromboembolic Disease, V2.2008 http://www. nccn.org/professionals/physician_gls/PDF/vte.pdf.

20. Trousseau A: Clinique Medicale l'Hotel-Dieu de Paris London: New Sydenham Society. Phlegmasia alba dolens 1865, 3:654-712.

21. Nijziel MR, van Oerle R, Hillen HF, Hamulyák K: From Trousseau to angiogenesis: the link between the haemostatic system and cancer. Neth J Med 2006, 64:403-410.

22. Caine GJ, Stonelake PS, Lip GY, Kehoe ST: The hypercoagulable state of malignancy: pathogenesis and current debate. Neoplasia 2002, 4:465-473.

23. Goldenberg N, Kahn SR, Solymoss S: Markers of coagulation and angiogenesis in cancer-associated venous thromboembolism. J Clin Oncol 2003, 21:4194-4199.

24. Floyd CM, Irani K, Kind PD, Kessler CM: von Willebrand factor interacts with malignant hematopoietic cell lines: evidence for the presence of specific binding sites and modification of von Willebrand factor structure and function. J Lab Clin Med 1992, 119:467-476.

25. Rickles FR, Falanga A: Molecular basis for the relationship between thrombosis and cancer. Thromb Res 2001, 102:V215-V224.

26. Amin A, Stemkowski S, Lin J, Yang G: Thromboprophylaxis rates in US medical centers: success or failure?. J Thromb Haemost 2007, 5:1610-1616.

27. Seddighzadeh A, Shetty R, Goldhaber SZ: Venous thromboembolism in patients with active cancer. Thromb Haemost 2007, 98:656-661.

28. Cohen AT, Tapson VF, Bergmann JF, Goldhaber SZ, Kakkar AK, Deslandes B, Huang W, Zayaruzny M, Emery L, Anderson FA Jr, ENDORSE Investigators: Venous thromboembolism risk and prophylaxis in the acute hospital care setting (ENDORSE study): a multinational cross-sectional study. Lancet 2008, 371:387-394.

29. Kakkar AK, Cohen AT, Tapson VF, Bergmann JF, Goldhaber SZ, Anderson FA: Venous thromboembolism risk and prophylaxis practices in surgical patients with active cancer: findings from the Global ENDORSE Survey [abstract]. Blood 2008, 112:984.

30. Monreal M, Falgá C, Valdés M, Suárez C, Gabriel F, Tolosa C, Montes J, Riete Investigators: Fatal pulmonary embolism and fatal bleeding in cancer patients with venous thromboembolism: findings from the RIETE registry. J Thromb Haemost 2006, 4:1950-1956.

31. Imberti D, Agnelli G, Ageno W, Moia M, Palareti G, Pistelli R, Rossi R, Verso M, MASTER Investigators: Clinical characteristics and management of cancer-associated acute venous thromboembolism: findings from the MASTER Registry. Haematologica 2008, 93:273-278.

32. Kuderer NM, Khorana AA, Lyman GH, Francis CW: A meta-analysis and systematic review of the efficacy and safety of anticoagulants as cancer treatment: impact on survival and bleeding complications. Cancer 2007, 110:1149-1161

33. Clagett GP, Reisch JS: Prevention of venous thromboembolism in general surgical patients. Results of meta-analysis. Ann Surg 1998, 208:227-240.

34. Mismetti P, Laporte $S$, Darmon JY, Buchmüller A, Decousus H: Meta-analysis of low-molecular-weight heparin in the prevention of venous thromboembolism in general surgery. Br J Surg 2001, 88:913-930.

35. Koch A, Ziegler S, Breitschwerdt H, Victor N: Low-molecular-weight heparin and unfractionated heparin in thrombosis prophylaxis: metaanalysis based on original patient data. Thromb Res 2001, 102:295-309.

36. Bergqvist D: Low-molecular-weight heparin for the prevention of venous thromboembolism after abdominal surgery. Br J Surg 2004, 91:965-974.

37. Freedman KB, Brookenthal KR, Fitzgerald RH Jr, Williams S, Lonner JH: A meta-analysis of thromboembolic prophylaxis following elective total hip arthroplasty. J Bone Joint Surg Am 2000, 82-A:929-938.

38. Leonardi MJ, MCGory ML, Ko CY: A systematic review of deep venous thrombosis prophylaxis in cancer patients: implications for improving quality. Ann Surg Oncol 2007, 14:929-936.

39. Gallus A, Cade J, Ockelford P, Hepburn S, Maas M, Magnani H, Bucknall T, Stevens J, Porteous F: Orgaran (Org 10172) or heparin for preventing venous thrombosis after elective surgery for malignant disease? A double-blind, randomized, multicentre comparison. Thromb Haemost 1993, 70:562-567.

40. ENOXACAN Study Group: Efficacy and safety of enoxaparin versus unfractionated heparin for prevention of deep vein thrombosis in elective cancer surgery: a double-blind randomized multicentre trial with venographic assessment. Br J Surg 1997, 84:1099-1103.

41. Heilmann L, Von Tempelhoff G-F, Herrle B, Hojnacki B, Schneider D, Michaelis HC, Wolf G: [Prevention of postoperative venous thrombosis. A randomized trial comparing low-dose heparin and low-molecular-weight heparin in gynaecological oncology]. Geburtsh Frauenheilk 1997, 57:1-6.

42. Baykal C, Al A, Demirtaş E, Ayhan A: Comparison of enoxaparin and standard heparin in gynaecologic oncologic surgery: a randomized prospective double-blind clinical study. Eur J Gynaecol Oncol 2001, 22:127-130.

43. McLeod RS, Geerts WH, Sniderman KW, Greenwood C, Gregoire RC, Taylor BM, Silverman RE, Atkinson KG, Burnstein M, Marshall JC, Burul CJ, Anderson DR, Ross T, Wilson SR, Barton P, Canadian Colorectal Surgery DVT Prophylaxis Trial investigators: Subcutaneous heparin versus lowmolecular-weight heparin as thromboprophylaxis in patients undergoing colorectal surgery: results of the canadian colorectal DVT prophylaxis trial: a randomized, double-blind trial. Ann Surg 2001, 233:438-444.

44. Agnelli G, Bergqvist D, Cohen AT, Gallus AS, Gent M, PEGASUS investigators: Randomized clinical trial of postoperative fondaparinux versus perioperative dalteparin for prevention of venous thromboembolism in high-risk abdominal surgery. Br J Surg 2005, 92:1212-1220.

45. Simonneau G, Laporte S, Mismetti P, Derlon A, Samii K, Samama CM, Bergman JF, FX140 Study Investigators: A randomized study comparing the efficacy and safety of nadroparin $2850 \mathrm{IU}(0.3 \mathrm{~mL})$ vs. enoxaparin $4000 \mathrm{IU}(40 \mathrm{mg})$ in the prevention of venous thromboembolism after colorectal surgery for cancer. J Thromb Haemost 2006, 4:1693-1700.

46. AkI EA, Terrenato I, Barba M, Sperati F, Sempos EV, Muti P, Cook DJ, Schünemann HJ: Low-molecular-weight heparin vs unfractionated heparin for perioperative thromboprophylaxis in patients with cancer: a systematic review and meta-analysis. Arch Intern Med 2008 168:1261-1269.

47. Comp PC, Spiro TE, Friedman RJ, Whitsett TL, Johnson GJ, Gardiner GA Jr, Landon GC, Jové M, Enoxaparin Clinical Trial Group: Prolonged enoxaparin therapy to prevent venous thromboembolism after primary hip or knee replacement. J Bone Joint Surg Am 2001, 83-A:336-345.

48. Bergqvist D, Agnelli G, Cohen AT, Eldor A, Nilsson PE, Le Moigne-Amrani A, Dietrich-Neto F, ENOXACAN II Investigators: Duration of prophylaxis against venous thromboembolism with enoxaparin after surgery for cancer. N Engl J Med 2002, 346:975-980.

49. Rasmussen MS, Jorgensen LN, Wille-Jørgensen P, Nielsen JD, Horn A, Mohn AC, Sømod L, Olsen B, FAME Investigators: Prolonged prophylaxis with dalteparin to prevent late thromboembolic complications in patients undergoing major abdominal surgery: a multicenter randomized open-label study. J Thromb Haemost 2006, 4:2384-2390.

50. Rasmussen MS, Wille-Jorgensen $P$, Jorgensen LN: Prolonged thromboprophylaxis with low-molecular-weight heparin (dalteparin) following major abdominal surgery for malignancy [abstract]. Blood 2003, 102:186.

51. Kahn SR, Panju A, Geerts W, Pineo GF, Desjardins L, Turpie AG, Glezer S, Thabane L, Sebaldt RJ, CURVE study investigators: Multicenter evaluation of the use of venous thromboembolism prophylaxis in acutely ill medical patients in Canada. Thromb Res 2007, 119:145-155.

52. Kakkar AK, Levine M, Pinedo HM, Wolff $R$, Wong J: Venous thrombosis in cancer patients: insights from the FRONTLINE survey. Oncologist 2003, 8:381-388.

53. Samama MM, Cohen AT, Darmon JY, Desjardins L, Eldor A, Janbon C, Leizorovicz A, Nguyen $\mathrm{H}$, Olsson CG, Turpie AG, Weisslinger N: A comparison of enoxaparin with placebo for the prevention of venous thromboembolism in acutely ill medical patients: Prophylaxis in Medical Patients with Enoxaparin Study Group. N Engl J Med 1999, 341:793-800.

54. Leizorovicz A, Cohen AT, Turpie AG, Olsson CG, Vaitkus PT, Goldhaber SZ, PREVENT Medical Thromboprophylaxis Study Group: Randomized, placebocontrolled trial of dalteparin for the prevention of venous thromboembolism in acutely ill medical patients. Circulation 2004, 110:874-879.

55. Cohen AT, Davidson BL, Gallus AS, Lassen MR, Prins MH, Tomkowski W, Turpie AG, Egberts JF, Lensing AW, ARTEMIS Investigators: Efficacy and safety of fondaparinux for the prevention of venous thromboembolism in older acute medical patients: randomized placebo controlled trial. BMJ 2006, 332:325-329

56. Alikhan R, Cohen AT, Combe S, Samama MM, Desjardins L, Eldor A, Janbon C, Leizorovicz A, Olsson CG, Turpie AG: Prevention of venous thromboembolism in medical patients with enoxaparin: a subgroup analysis of the MEDENOX study. Blood Coagul Fibrinolysis 2003, 14:341-346. 
57. European Medicines Agency. http://www.emea.europa.eu/humandocs/ PDFs/EPAR/arixtra/011502en6.pdf.

58. Sud R, Khorana AA: Cancer-associated thrombosis: risk factors, candidate biomarkers and a risk model. Thromb Res 2009, 4:S18-21.

59. Khorana AA, Kuderer NM, Culakova E, Lyman GH, Francis CW: Development and validation of a predictive model for chemotherapy-associated thrombosis. Blood 2008, 111:4902-7.

60. Connolly GC, Khorana AA: Risk stratification for cancer-associated venous thromboembolism. Best Pract Res Clin Haematol 2009, 22:35-47.

61. AkI EA, Rohilla S, Barba M, Sperati F, Terrenato I, Muti P, Bdair F, Schünemann $\mathrm{HJ}$ : Anticoagulation for the initial treatment of venous thromboembolism in patients with cancer: a systematic review. Cancer 2008, 113:1685-94

62. Iorio A, Guercini F, Pini M: Low-molecular-weight heparin for the longterm treatment of symptomatic venous thromboembolism: metaanalysis of the randomized comparisons with oral anticoagulants. $J$ Thromb Haemost 2003, 1:1906-1913.

63. Lee AY, Levine MN, Baker RI, Bowden C, Kakkar AK, Prins M, Rickles FR, Julian JA, Haley S, Kovacs MJ, Gent M, Randomized Comparison of LowMolecular-Weight Heparin versus Oral Anticoagulant Therapy for the Prevention of Recurrent Venous Thromboembolism in Patients with Cancer (CLOT) Investigators: Low-molecular-weight heparin versus a coumarin for the prevention of recurrent venous thromboembolism in patients with cancer. N Engl J Med 2003, 349:146-153.

64. Hull RD, Pineo GF, Brant RF, Mah AF, Burke N, Dear R, Wong T, Cook R, Solymoss S, Poon MC, Raskob G, LITE Trial Investigators: Long-term lowmolecular-weight heparin versus usual care in proximal-vein thrombosis patients with cancer. Am J Med 2006, 119:1062-1072.

65. Akl EA, Muti $P$, Schünemann $H J$ : Anticoagulation in patients with cancer: an overview of reviews. Pol Arch Med Wewn 2008, 118:183-93.

66. Raschke RA, Gollihare B, Peirce JC: The effectiveness of implementing the weight-based heparin nomogram as a practice guideline. Arch Intern Med 1996, 156:1645-1649

67. Hull RD, Raskob GE, Hirsh J, Jay RM, Leclerc JR, Geerts WH, Rosenbloom D, Sackett DL, Anderson C, Harrison L: Continuous intravenous heparin compared with intermittent subcutaneous heparin in the initial treatment of proximal-vein thrombosis. N Engl J Med 1986, 315:1109-1114.

68. Hirsh J, Bauer KA, Donati MB, Gould M, Samama MM, Weitz Jl, American College of Chest Physicians: Parenteral anticoagulants: American College of Chest Physicians Evidence-Based Clinical Practice Guidelines. Chest , 8 2008, 133(6 Suppl):141S-159S.

69. Handeland GF, Abildgaard U, Holm HA, Arnesen KE: Dose adjusted heparin treatment of deep venous thrombosis: a comparison of unfractionated and low-molecular-weight heparin. Eur J Clin Pharmacol 1990, 39:107-112.

70. Hirsh J, Levine MN: Low-molecular-weight heparin. Blood 1992, 79:1-17.

71. Ansell J, Hirsh J, Hylek E, Jacobson A, Crowther M, Palareti G, American College of Chest Physicians: Pharmacology and management of the vitamin K antagonists: American College of Chest Physicians EvidenceBased Clinical Practice Guidelines. Chest , 8 2008, 133(6 Suppl):160S-1985.

72. Rose AJ, Sharman JP, Ozonoff A, Henault LE, Hylek EM: Effectiveness of warfarin among patients with cancer. J Gen Intern Med 2007, 22:997-1002.

73. Morris PG, Davenport C, O'Dwyer D, O'Callaghan C, Breathnach OS, Grogan L: Practical problems and resource implications with the use of warfarin for venous thromboembolism in patients with cancer. Ir J Med Sci 2007, 176:165-168.

74. O'Reilly RA: Warfarin metabolism and drug-drug interactions. The New Dimensions of Warfarin Prophylaxis: Advances in Experimental Medicine and Biology New York, NY: PlenumWessler S, Becker CG, Nemerson Y 1986, 198:205-212

75. Colwell CW Jr, Pulido P, Hardwick ME, Morris BA: Patient compliance with outpatient prophylaxis: an observational study. Orthopedics 2005, 28:143-147.

76. Maxwell GL, Synan I, Hayes RP, Clarke-Pearson DL: Preference and compliance in postoperative thromboembolism prophylaxis among gynecologic oncology patients. Obstet Gynecol 2002, 100:451-455.

77. Noble SI, Hood K, Finlay IG: The use of long-term low-molecular weight heparin for the treatment of venous thromboembolism in palliative care patients with advanced cancer: a case series of sixty two patients. Palliat Med 2007, 21:473-476.
78. Noble SI, Finlay IG: Is long-term low-molecular-weight heparin acceptable to palliative care patients in the treatment of cancer related venous thromboembolism? A qualitative study. Palliat Med 2005, 19:197-201.

79. Dranitsaris G, Vincent M, Crowther M: Dalteparin versus warfarin for the prevention of recurrent venous thromboembolic events in cancer patients: a pharmacoeconomic analysis. Pharmacoeconomics 2006, 24:593-607.

80. Spyropoulos AC, Hurley JS, Ciesla GN, de Lissovoy G: Management of acute proximal deep vein thrombosis: pharmacoeconomic evaluation of outpatient treatment with enoxaparin vs inpatient treatment with unfractionated heparin. Chest 2002, 122:108-114.

81. Spyropoulos AC, Lin J: Direct medical costs of venous thromboembolism and subsequent hospital readmission rates: an administrative claims analysis from 30 managed care organizations. J Manag Care Pharm 2007, 13:475-486.

82. MacDougall DA, Feliu AL, Boccuzzi SJ, Lin J: Economic burden of deepvein thrombosis, pulmonary embolism, and post-thrombotic syndrome. Am J Health Syst Pharm 2006, 63:S5-15.

83. de Lissovoy G, Yusen RD, Spiro TE, Krupski WC, Champion AH, Sorensen SV: Cost for inpatient care of venous thrombosis: a trial of enoxaparin vs standard heparin. Arch Intern Med 2000, 160:3160-3165.

84. Estrada CA, Mansfield CJ, Heudebert GR: Cost-effectiveness of lowmolecular-weight heparin in the treatment of proximal deep vein thrombosis. J Gen Intern Med 2001, 15:108-115.

85. Goldstein JL, Larson LR, Yamashita BD, Fain JM, Schumock GT: Lowmolecular-weight heparin versus unfractionated heparin in the colonoscopy peri-procedure period: a cost modeling study. Am J Gastroenterol 2001, 6:2360-2366.

86. Amorosi SL, Tsilimingras K, Thompson D, Fanikos J, Weinstein MC, Goldhaber SZ: Cost analysis of "bridging therapy" with low-molecularweight heparin versus unfractionated heparin during temporary interruption of chronic anticoagulation. Am J Cardiol 2004, 93:509-511.

87. Spyropoulos AC, Frost FJ, Hurley JS, Roberts M: Costs and clinical outcomes associated with low-molecular-weight heparin vs unfractionated heparin for perioperative bridging in patients receiving long-term oral anticoagulant therapy. Chest 2004, 125:1642-1650.

88. Nerurkar J, Wade WE, Martin BC: Cost/death averted with venous thromboembolism prophylaxis in patients undergoing total knee replacement or knee arthroplasty. Pharmacotherapy 2002, 22:990-1000.

89. Sarasin FP, Bounameaux H: Out of hospital antithrombotic prophylaxis after total hip replacement: low-molecular-weight heparin, warfarin, aspirin or nothing? A cost-effectiveness analysis. Thromb Haemost 2002, 87:586-592.

90. Laupacis A, Feeny D, Detsky AS, Tugwell PX: How attractive does a new technology have to be to warrant adoption and utilization? Tentative guidelines for using clinical and economic evaluations. CMAJ 1992, 146:473-481.

91. Klerk CP, Smorenburg SM, Otten HM, Lensing AW, Prins MH, Piovella F, Prandoni P, Bos MM, Richel DJ, van Tienhoven G, Büller HR: The effect of low-molecular-weight heparin on survival in patients with advanced malignancy. J Clin Oncol 2005, 23:2130-2135.

92. Kakkar AK, Levine MN, Kadziola Z, Lemoine NR, Low V, Patel HK, Rustin G, Thomas M, Quigley M, Williamson RC: Low-molecular-weight heparin, therapy with dalteparin, and survival in advanced cancer: the fragmin advanced malignancy outcome study (FAMOUS). J Clin Oncol 2004, 22:1944-1948.

93. Lee AY, Rickles FR, Julian JA, Gent M, Baker RI, Bowden C, Kakkar AK, Prins M, Levine MN: Randomized comparison of low-molecular-weight heparin and coumarin derivatives on the survival of patients with cancer and venous thromboembolism. J Clin Oncol 2005, 23:2123-2129.

94. Zacharski LR, Henderson WG, Rickles FR, Forman WB, Cornell CJ Jr, Forcier RJ, Edwards R, Headley E, Kim SH, O'Donnell JR, O'Dell R, Tornyos K, Kwaan HC: Effect of warfarin on survival in small cell carcinoma of the lung. Veterans Administration Study No. 75. JAMA 1981, 245:831-835.

95. Schulman S, Lindmarker P: Incidence of cancer after prophylaxis with warfarin against recurrent venous thromboembolism. Duration of Anticoagulation Trial. N Engl J Med 2000, 342:1953-1958.

96. Tagalakis V, Tamim H, Blostein M, Collet JP, Hanley JA, Kahn SR: Use of warfarin and risk of urogenital cancer: a population-based, nested casecontrol study. Lancet Oncol 2007, 8:395-402. 
97. AkI EA, van Doormaal FF, Barba M, Kamath G, Kim SY, Kuipers S, Middeldorp S, Yosuico V, Dickinson HO, Schünemann HJ: Parenteral anticoagulation for prolonging survival in patients with cancer who have no other indication for anticoagulation. Cochrane Database Syst Rev 2007, 18:CD006652.

98. Mousa SA: Role of current and emerging antithrombotics in thrombosis and cancer. Timely Top Med Cardiovasc Dis 2006, 10:E19.

99. Stevenson JL, Choi SH, Varki A: Differential metastasis inhibition by clinically relevant levels of heparins-correlation with selectin inhibition, not antithrombotic activity. Clin Cancer Res 2005, 11:7003-7011.

100. Mellor P, Harvey JR, Murphy K, Pye D, O'Boyle G, Lennard TW, Kirby JA, Ali S: Modulatory effects of heparin and short-length oligosaccharides of heparin on the metastasis and growth of LMD MDA-MB 231 breast cancer cells in vivo. Br J Cancer 2007, 97:761-768.

101. Folkman J, Langer R, Linhardt RJ, Haudenschild C, Taylor S: Angiogenesis inhibition and tumor regression caused by heparin or a heparin fragment in the presence of cortisone. Science 1983, 221:719-725.

102. Mousa SA, Mohamed S: Inhibition of endothelial cell tube formation by the low-molecular-weight heparin, tinzaparin, is mediated by tissue factor pathway inhibitor. Thromb Haemost 2004, 92:627-633.

103. Smorenburg SM, Van Noorden CJ: The complex effects of heparins on cancer progression and metastasis in experimental studies. Pharmacol Rev 2001, 53:93-105.

104. Fareed J, Ma Q, Florian M, Maddineni J, lqbal O, Hoppensteadt DA, Bick RL: Differentiation of low-molecular-weight heparins: impact on the future of the management of thrombosis. Semin Thromb Hemost 2004, 30:89-104.

105. Jeske WP, Walenga JM, Hoppensteadt DA, Vandenberg C, Brubaker A, Adiguzel C, Bakhos M, Fareed J: Differentiating low-molecular-weight heparins based on chemical, biological, and pharmacologic properties: implications for the development of generic versions of low-molecularweight heparins. Semin Thromb Hemost 2008, 34:74-85.

106. Casu B, Vlodavsky I, Sanderson RD: Non-anticoagulant heparins and inhibition of cancer. Pathophysiol Haemost Thromb 2008, 36:195-203.

107. Fareed J, labal O, Cunanan J, Demir M, Wahi R, Clarke M, Adiguzel C, Bick R: Changing trends in anti-coagulant therapies. Are heparins and oral anticoagulants challenged?. Int Angiol 2008, 27:176-192.

108. Weitz Jl, Hirsh J, Samama MM, American College of Chest Physicians: New antithrombotic drugs: American College of Chest Physicians EvidenceBased Clinical Practice Guidelines. Chest , 8 2008, 133:234S-256S

109. Levine MN: New antithrombotic drugs: potential for use in oncology. J Clin Oncol 2009, 27:4912-8.

110. Hoppensteadt D, Jeske W, Walenga JM, Fareed J: AVE5026: A new hemisynthetic ultra low molecular weight heparin (ULMWH) with enriched anti-Xa activity and enhanced antithrombotic activity for management of cancer associated thrombosis. J Clin Oncol 2008, 26:abstr 14653.

111. Eriksson Bl, Friedman R: Dabigatran Etexilate: Pivotal Trials for Venous Thromboembolism Prophylaxis After Hip or Knee Arthroplasty. Clin Appl Thromb Hemost 2009.

112. Eriksson BI, Borris LC, Friedman RJ, Haas S, Huisman MV, Kakkar AK, Bandel TJ, Beckmann H, Muehlhofer E, Misselwitz F, Geerts W, RECORD1 Study Group: Rivaroxaban versus enoxaparin for thromboprophylaxis after hip arthroplasty. N Engl J Med 2008, 358:2765-75.

113. Turpie AG, Lassen MR, Davidson BL, Bauer KA, Gent M, Kwong LM, Cushner FD, Lotke PA, Berkowitz SD, Bandel TJ, Benson A, Misselwitz F, Fisher WD, RECORD4 Investigators: Rivaroxaban versus enoxaparin for thromboprophylaxis after total knee arthroplasty (RECORD4): a randomised trial. Lancet 2009, 373:1673-80.

doi:10.1186/1756-8722-3-3

Cite this article as: Robert: The potential benefits of low-molecularweight heparins in cancer patients. Journal of Hematology \& Oncology 2010 3:3.

\section{Submit your next manuscript to BioMed Central and take full advantage of:}

- Convenient online submission

- Thorough peer review

- No space constraints or color figure charges

- Immediate publication on acceptance

- Inclusion in PubMed, CAS, Scopus and Google Scholar

- Research which is freely available for redistribution 